\title{
CONTESTATION ON POLITICAL SPACE BETWEEN ISLAMISM AND ISLAMIC GROUP IN PRESIDENTIAL ELECTION 2019
}

\author{
Ali Akhbar Abaib Mas Rabbani Lubis \\ Progam Doktoral Universitas Islam Negeri Sunan Kalijaga \\ Yogyakarta, Indonesia \\ email: lubismymarga@gmail.com
}

\begin{abstract}
This paper explains the struggle for political space between Islamism and Islamic groups in the 2019 Presidential Election. The origin of the struggle for political space is closely related to the early history of Indonesian independence. The author considers that historical events are something important to analyze the 2019 Presidential Election issues. This study is a qualitative study using library data through descriptive analysis. The data analysis phase includes data reduction, data presentation, and drawing conclusions. The author uses the triadic concept approach to spatial practise, representations of space, and representational spaces as a theoretical framework for analysis. The discussion of this article results in the conclusion that the "failure of political Islam" in the 2019 Presidential Election cannot be enforced. The 2019 presidential election showed that the struggle for political space was dominated by the Islamism group supporting Prabowo-Sandi and the Islamic group supporting Jokowi-Ma'ruf. Other explanations reveal that the debate and struggle over the political space of the Indonesian State is the impact of the historical cycle of independence. In the context of democracy, the political struggle over space is permissible, but every dynamic of the struggle over political space must be constitutional.

الملخص: ستشرح هذه المقالة النضال من أجل الفضاء السياسي بين الإسلامية والجماعات

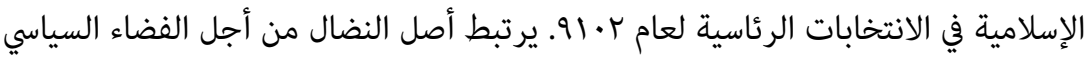

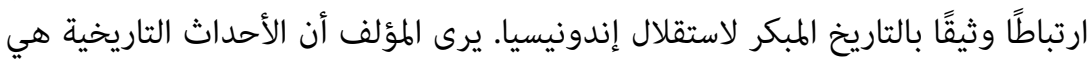


شيء مهم لتحليل قضايا الانتخابات الرئاسية لعام r.41. هذه الورقة عبارة عن دراسة

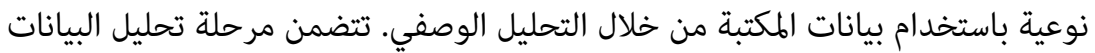

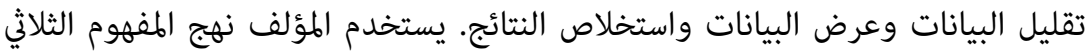

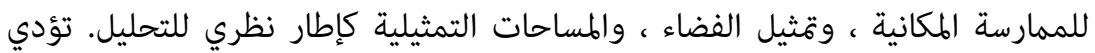

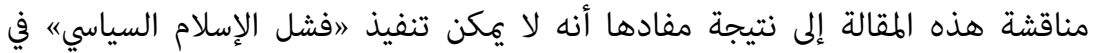

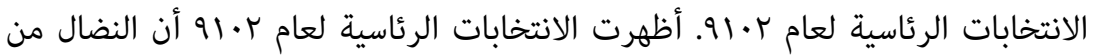

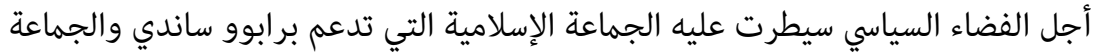

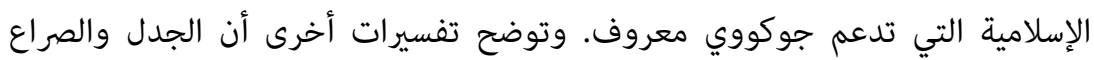

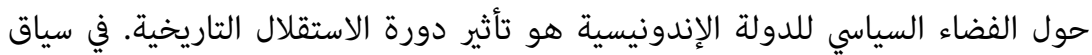

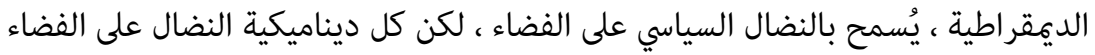
السياسي يجب أن تكون دستورية.

Abstrak: Artikel ini akan menjelaskan perebutan politik ruang antara kelompok islamisme dan islami pada Pilpres 2019. Asal mula perebutan politik ruang berhubungan erat dengan sejarah awal kemerdekaan bangsa Indonesia. Penulis memandang bahwa peristiwa sejarah merupakan sesuatu yang penting untuk menganalisis persoalan Pilpres 2019. Tulisan ini merupakan penelitian kualitatif dengan menggunakan data kepustakaan melalui analisis deskriptif. Tahap analisis data meliputi reduksi data, penyajian data, dan penarikan kesimpulan. Penulis menggunakan pendekatan konsep triadik spatial practice, representations of space, dan representational spaces sebagai kerangka teoritik analisis. Pembahasan artikel ini menghasilkan kesimpulan bahwa "kegagalan Islam politik" dalam Pilpres 2019 tidak bisa diberlakukan. Pilpres 2019 memperlihatkan bahwa perebutan politik ruang di dominasi oleh kelompok Islamisme pendukung Prabowo-Sandi dan kelompok Islami pendukung Jokowi-Ma'ruf. Penjelasan lainnya mengungkapkan bahwa perdebatan dan perebutan politik ruang Negara Indonesia ini merupakan imbas dari siklus sejarah kemerdekaan. Dalam konteks demokrasi, perebutan politik ruang diperbolehkan, namun setiap dinamika perebutan politik ruang harus konstitusional.

Keywords: Political Space, Islamism, Islamic, Presidential Election 2019. 


\section{INTRODUCTION}

Starting this discussion, the author will explain the theme of the General Election in the Presidential Election 2019. The explanation is presented differently in delivering the approach in a perspective that has never been touched by experts. The struggle for space politics in Indonesia is a repetition of the early history of independence because Indonesia as a country with an independent society (social space) is part of social products. It is relevant to quote the term from Henri Lefebvre, to emphasize the purpose of social products that:

"(Social) Space is a (social) product. This propotition might appear to border on the tautologous, and hence on the obvious. There is good reason, however, to examine it carefully, to consider its implications and consequences before accepting it... the space thus the produced also serves as a tool of thought and of action; that in addition to being a means of production it is also a means of control, and space and hence of domination, of power; yet that as such, its escapes in part from those who would make use of it. The social and political (state) forces which engendered this space now seek, but fail, to master it completely; the very agency that has forced spatial reality towards a sort of uncontrollable autonomy now strives to run it into the ground, the shackle and enslave it". ${ }^{1}$

The resulting space (read: Indonesian independence), if inspired by quotations turns out not only to function as a result of the thoughts and actions of the founders of the nation ${ }^{2}$ but there are efforts to control and dominate the power of the country independently so that it is free from colonialism. The positive is that, but from these seeds, there are sharp differences in perceptions and concepts about the country to be occupied. These can be grouped into 2 camps, namely representatives of formal-formal Islamic groups and nationalist groups. In short, the author maps it into Islamism and Islamic groups. This dynamic is

1 Henri Lefebvre, The Production of Space, ed. Tranlated by Donald NicholsonSmith (Oxford UK, Cambridge, Massachusetts, USA: Basil Blackwell, 1991), 26.

2 The word 'founding father' indicates as if no female members were participating in BPUPKI and fighting for Indonesian independence, female BPUPKI members included: Mrs Maria Ulfah Santoso and Ny. Siti Sukaptinah Soenarjo Mangoenpuspito..Departemen Pendidikan dan Kebudayaan, Tokoh-Tokoh Badan Penyelidik Usaha-Usaha Persiapan Kemerdekaan Indonesia II (Jakarta: Proyek Inventarisasi dan Dokumentasi Sejarah Nasional, Direktorat Sejarah dan Nilai Tradisional, 1993), 176-77. 
more likely to be seen as a shadow of Political Islam in a series of stories about Indonesia's struggle for independence. Political Islam has been defined as an expression of Islam in the political sphere and it can also be Islam that is expressed/manifested in a political language, where Islam can emerge as a discourse or social-political movement with political objectives. ${ }^{3}$ Expressions, manifestations, discourses, political Islamic movements have a variety of colours, especially in Indonesia. But in broad outline, the author simplifies it with Islamism and Islamic groups as mentioned above to limit this focus.

Research conducted by Masdar Hilmy who analyzed the configuration of radical Islamism, indicated that the ideology of Islamism will never die just because state institutions use a security approach to eliminate the ideology. Radical Islamism always uses opport unities through socio-political factors, actors or institutions and others to propose alternative ideologies. ${ }^{4}$ Other research conducted by Syahrir Karim, et al further explores the features and patterns of Islamism in Indonesia during the reform period, at least there are four characteristics which include: 1) proposing Islam as the only basis in transforming society, 2) recognition of Islam as an ideology (Islamism), 3) realizing an Islamic state, and 4) sharia law as a legal basis in life. This is confirmed again, that: "Islamism both exixting in intra and extra-parliamentary plays a pivotal role in political process in Indonesia, mainly in the growth of democracy." ${ }^{5}$ Dirk Tomsa's research further analyzed the development of the Prosperous Justice Party (PKS) as one of the Islamic parties in Indonesia, the results achieved in his research that PKS developed into a nationalistreligious party, - but still very conservative. Furthermore, PKS seems to be at risk of being co-opted into Indonesia's traditional power politics, for example in democratic law-making processes from the results of PKS inputs which tend to be discriminatory towards women, - this is because in its political practice, PKS neglects the

3 AE Priyono, "Masa Depan Islam-Politik Dan Islamisme Di Indonesia," Monograf Embun Kalimasada, no. 2 (2019): 1.

4 Masdar Hilmy, "The Configuration of Radical Islamism in Indonesia: Some Contemporery Assessments and Trajectories," Al-Tahrir 14, no. 1 (2014): 1-21.

5 Syahrir Karim, Samsu Adabi Mamat, and Bayu Taufiq Possumah, "Islamism and Democratization in Indonesia Post-Reformation Era: Socio-Political Analysis," International Journal of Islamic Thought 6 (2014): 85. 
role of women which can also be seen in the organizational structure. ${ }^{6}$ Research conducted by Leonard C. Sebastian and Alexander R. Arfianto that the phenomenon of the rise of Islamism was marked in the Islamic defence action and the case of Basuki Tjahaja Punama (Ahok) in Indonesia after the reformation. The most crucial thing in this phenomenon is by factors: 1) can attract solidarity in persuading other Muslims, 2) use religious missionary institutions, and 3) seek allies in national and local government institutions so that the policy agenda can be implemented, while moderate Islamic groups lose their appeal. ${ }^{7}$

The explanation above indicates that the group of Islamism is the colour of the Islamic ideology that is contrary to the state ideology, of course, to establish an Islamic state, especially in Indonesia. Of course, this research helps see the extent of the development of Islamism in Indonesia and how it moves, this research seems to occupy a different portion from previous research. The most fundamental problem in this paper is that political Islam in a discourse is expressed and manifested by a form of movement, instead of controlling religion. All religious propositions (read: Islam) appear on the surface and each considers a truth. This is the author's interest to reopen the historical tap in seeing and understanding what can be drawn from his message when looking at the context that occurred in the 2019 Presidential Election regarding political Islam. On that basis, I will discuss the struggle for the NKRI space between Islamism and Islamic groups, as well as look at the reflection and relevance of the history of Indonesia's independence over differences in perceptions and concepts about the state which is the object of debate. Therefore, the authors use literature studies critically in the form of descriptive analysis. Stages of data analysis in this study include data reduction, data presentation, and drawing conclusions so that in operational discussions using a conceptual triadic approach, as a theoretical framework for analysis, includes: spatial practice,

${ }^{6}$ Dirk Tomsa, "Moderating Islamism in Indonesia: Tracing Patterns of Party Change in the Prosperous Justice Party," Political Research Quarterly 65, no. 3 (2012): 486-98.

7 Leonard C. Sebastian and Alexander R. Arifianto, "From Civil Islam toward NKRI Bersyariah? Understanding Rising Islamism in Post-Reformasi Indonesia," in Proceedings of the Third International Conference on Social and Political Sciences (ICSPS 2017), 2017, 301-16. 
representations of space, dan representational spaces. ${ }^{8}$ The purpose of using this approach is to see the democratic cycle from the history of independence to the contemporary, especially regarding political Islam as part of the space produced in democracy in Indonesia.

\section{THE UNTOUCHED TO THE HISTORY OF INDEPENDENCE IN INDONESIA}

BPUPK arranged two meetings or hearings in the history of Indonesian independence, namely Plenary I (29 May-1 June 1945) and Plenary II (10 July-17 July 1945). There are various opinions in the study and official statements regarding the formation of BPUPK. Some argue that BPUPK was formed on March $1,1945,{ }^{9}$ but another study said that BPUPK was established on April 29, 1945. ${ }^{10}$ According to Ahmad Syafi'i Ma'arif, the composition of BPUPK members was originally amounting to 62 people (members originating from Original Indonesia) then added 6 people to 68 members of, so that overall BPUPK in its initial membership there were 60 people plus one chairman (Radjiman Wediodiningrat) and two deputy chairs (Itibangase Yoshio and RP Soeroso), including representatives from Japan, becoming 63 members then increased by another 6 people and added by 7 special members consisting of Japanese representatives. ${ }^{11}$

The spatial practice ${ }^{12}$ was officially carried out by the nation's founders at BPUPK. Investigation Agency for the Preparation for Independence/Badan Penyelidik Usaha Persiapan Kemerdekaan (BPUPK) is one of the terms chosen in this paper. Another similar term is the Indonesian Independence Preparatory Agency for Investigation/

8 The triadic theoretical concept was first introduced by Henri Lefebvre to explain the production of space. Lefebvre, The Production of Space, 33.

9 Saifudin, "Lahirnya UUD 1945: Suatu Tinjauan Historis Penyusunan Dan Penetapan UUD 1945," Unisia 3, no. 49 (2003): 296.

${ }^{10}$ Ali Akhbar Abaib Mas Rabbani Lubis, Ilmu Hukum Dalam Simpul Siyasah Dusturiyah: Refleksi Atas Teori Dan Praktek Hukum Tata Negara Di Indonesia (Yogyakarta: Semesta Aksara, 2019), 181; Yudi Latif, Negara Paripurna; Historitas, Rasionalitas, Dan Aktualisasi Pancasila, 2nd ed. (Jakarta: PT Gramedia Pustaka Utama, 2011), 9.

${ }^{11}$ Lubis, Ilmu Hukum Dalam Simpul Siyasah Dusturiyah: Refleksi Atas Teori Dan Praktek Hukum Tata Negara Di Indonesia, 182.

${ }^{12}$ Spatial practice refers to the dimension in the arena of practice activities and social relations that allow the formation of space. The spatial practice is explicitly referred to as dialectics of social interaction because in that space there must always be social relations and activities. Lefebvre, The Production of Space, 38. 
Badan Penyelidik Usaha-Usaha Persiapan Kemerdekaan Indonesia (BPUPKI). Another term from Muhammad Yamin's speech notes is Free Indonesian Investigation Committee/Panitia Penyelidikan Indonesia Merdeka". ${ }^{13}$ The term Mohammad Hatta used when commenting on Muhammad Yamin was "Committee on Indonesia's IndependenceEfforts/PanitiaUsaha-usaha Kemerdekaan Indonesia. ${ }^{14}$ Meanwhile, other terms such as the Agency for Investigation of Indonesian Preparatory Efforts/Badan untuk Menyelidiki UsahaUsaha Persiapan Indonesia, ${ }^{15}$ and certainly the term refers to Dokuritsu Zyunbi Tyoosakai as in Soekarno's speech notes ${ }^{16}$ and other study literature. Because BPUPK itself was formed by the Japanese government in Indonesia, with the task of fighting for an independent Indonesia. As a promise to be given full recognition by the Japanese Government of Indonesia's independence officially following the formal requirements of international law. It should be underlined that Indonesia is not merely granted its independence by the Japanese government, but is given recognition as a condition of International Law (Internasionaalrecht).

The requirements of international law at that time made it very easy for countries that wanted independence, such as the explanation of Soekarno's speech on June 1, 1945, which for three consecutive days there was no clear agreement on consensus before Soekarno appeared to carry a historic message in his speech at the BPUPKI session, as follows:

"Ladies and Gentlemen! We are now encountering highly important time in our history. Do not we know, as noted by tens of speakers, that actually internasionaalrecht, international laws, facilitate our jobs? To establish, launch, and recognize an independent country, there are no such extremily compliacated

${ }^{13}$ Himpunan Risalah Sidang-Sindang, Dari Badan Penyelidik Usaha Persiapan Kemerdekaan Indonesia (BPUPKI) Tanggal 29 Mei 1945-16 Juli 1945 dan Panitia Persiapan Kemerdekaan Indonesia (PPKI) Tanggal 18 dan 19 Agust us 1945 (Indonesia, n.d.), 4.

${ }^{14}$ Moh. Mahfud MD, "Pancasila Sebagai Hasil Karya Dan Milik Bersama," Kongres Pancasila (Yogyakarta, 2009), 14.

${ }^{15}$ Sidang-Sindang, Dari Badan Penyelidik Usaha Persiapan Kemerdekaan Indonesia (BPUPKI) Tanggal 29 Mei 1945-16 Juli 1945 dan Panitia Persiapan Kemerdekaan Indonesia (PPKI) Tanggal 18 dan 19 Agustus 1945, 80.

${ }^{16}$ Sidang-Sindang, 57. 
requirements, No!. This only requires earth, people, and solid government!. That's all according to internasionaalrecht. These are enough, brothers!. as long as soil, people, and government exists, and we gain recognition from another independent country, this independent country already had name." 17

Allegedly in the excerpt of the speech above that the speaker in the course of the BPUPKI session before Sukarno appeared on June 1, 1945, many speakers had offered proposals regarding independence preparation such as the form of the state, the basis of state philosophy, state borders, draft laws and so forth. It should also be noted that there is no historical record in the Plenary Session I of BPUPKI, which was found to be related to speeches delivered by leaders who fought for an Islamic state legally-formally in championing that the state, government, and regulations are legally-formally based on Islam. As has been confirmed by RM A.B Kusuma and B. J Boland, as quoted by Mahfudz MD, as follows:

“...if we refer to Yamin's source (Manuscript Preparation for the 1945 Constitution) no speeches were delivered by Islamic leaders at the BPUPKI Plenary I on the second day (May 30, 1945), but from the book of RM A.B. Kusuma about the emergence of the 1945 Constitution, it is found information that apparently there were brief notes (not a speech) about the proposals from the Islamic group. According to BJ Boland, on the second day what was debated was the proposals for the basis of the Islamic state by representatives of the Islamic groups who sat on BPUPKI. Boland's conclusion is plausible for two reasons: first, when starting his speech on 31 May1945, Soepomo stated that in the discussions in the previous days the proposals had been submitted from national and Islamic groups; second, in the fact that follows later it was fully believed that at the BPUPKI session there has been a debate and argument with a very high level of rhetoric; that is, even though the contents of the speeches of representatives of the Islamic groups were not written or transcribed, the historical actors justified the very rhetorical argument that took place". ${ }^{18}$

\footnotetext{
${ }^{17}$ Sidang-Sindang, 62.

${ }^{18}$ MD, "Pancasila Sebagai Hasil Karya Dan Milik Bersama," 10.
} 
There are some historical gaps in BPUPK's Plenary Session I that did not receive much attention, when looking at the notes above and other studies that provided information in the dynamics of BPUPKI's Plenary Session I. Reiterate the above quote, B. J Boland, about Muhammad Yamin, that: "Unfortunately, yamin's work does not give the speeches and remarks made by Islamic leaders such as Bagus dan Halim during this first session of the commitee of 62. the three orators - Yamin $n$ Soekarno - clearly made their choice for a national pancasila state". ${ }^{19}$

There seems to be a political struggle over space in the history of the formation of the State in Indonesia, so that part of the history of the establishment of the Indonesian state was deliberately buried. Thus, an interest of the nationalist group would be to control the state (representations of space) ${ }^{20}$. The historical vacuum is among others; first, none of the academics and historical actors documented the speeches during the BPUPKI session against representatives of groups who fought for an Islamic state legally as a formal archive. Secondly, if there is even a proposal from a group representative who fights for an Islamic state legally-formally in the form of a short note, of course, it is very difficult for the writer to state; "That the paper on historical evidence in the BPUPKI session is very objective". The minimum historical actors of the group who fought for an a legitimate Islamic state should formally copy their notes in the Plenary Session I of BPUPKI in writing as a form of historical heritage, ahead of Indonesia's independence. Third, even though there are brief expressions from the contents of Sukarno's speech about the proposal of representatives of figures who fight for an Islamic state legallyformally about the form of the state, the basis of the state, and those related to it, it still has a historical vacuum due to the record/material no recordings were found in the form of speeches or brief proposals.

However, the struggle to legally make the formal Indonesian state succeed. Moh. Mahfudz MD explained that the second plenary session of BPUPK on July 10-16 actually agreed on the Jakarta Charter which

${ }^{19}$ B. J. Boland, The Struggle of Islam in Modern Indonesia (Leiden, The Netherlends: Brill, 2014), 23.

20 "Representations of Space, which are tied to the relations of production and to the 'order' which those relations impose, and hence to knowledge, to sign, to codes, and to 'frontal' relations". Lefebvre, The Production of Space, 33. 
in its Mukaddimah draft recognized Islam as a special state base for Muslims as set out in the first precepts with the phrase "Ketuhanan dengan kewajiban menjalankan Syari'at Islam bagi Pemeluknya". ${ }^{21}$ The Pancasila formula regarding 'Ketuhanan' is positioned to be the first precepts and the first clause of the precepts added with the obligation to carry out Islamic shari'ah for its adherents. However, Islam is still not used as a basis for the state or state religion, because the precepts emphasized in the first clause of the precepts refer to the Islamic sharia implementation for its adherents, not for all religious adherents. Finally, the 9 (nine) committee agreement was accepted on July 11, 1945, then the Committee submitted the draft constitution on July 13, 1945..$^{22}$ On 14 July 1945, it was ratified by agreeing on its contents as a state base, until 16 July 1945 BPUPKI Plenary Session II endorsed the draft constitution that would be made a written constitution for an independent Indonesia, at the end of the Plenary Session II on 17 July 1945, agreed based on the state and the draft constitution, and the Plenary Session of the BPUPKI 1945 was officially dissolved. ${ }^{23}$ From this, a new problem arises because the first precepts in the basic legal politics of the state are still unable to accommodate the ideals of a pluralistic nation.

Things that need to be touched about the response from Mr. J. Latuharhary on 11 July 111945, including:

"This would have serious consequences, for example with other religions. Therefore, I hope that in basic law, although this applies for a while, in this case seeds or possibilities may not be interpreted in various forms. I suggest that in the basic law there is clear article 1 so that there is no possibility of anything that can bring displeasure to the group concerned". ${ }^{24}$

A quite memorable consideration in the history of the standing of the Indonesian state is because Lat uharhary very much did not accept

${ }^{21}$ Moh. Mahfud MD, Perdebatan Hukum Tata Negara (Jakarta: Rajawali Pers, 2010), 240; MD, "Pancasila Sebagai Hasil Karya Dan Milik Bersama," 3.

${ }_{22}$ Moh. Mahfud MD, Politik Hukum Di Indonesia, 4th ed. (Jakarta: Rajawali Pers, 2011), 37.

${ }^{23}$ MD, Politik Hukum Di Indonesia; MD, "Pancasila Sebagai Hasil Karya Dan Milik Bersama," 3.

${ }^{24}$ Latif, Negara Paripurna; Historitas, Rasionalitas, Dan Aktualisasi Pancasila, 26. 
the seven words in the precepts of the Godhead (sila Ketuhanan). After all, the consequences could result in division. Lutuharhary explicitly rejected Wahid Hasyim's proposal to establish an Islamic state, because the proposal and opinion would endanger the unity and unity of Indonesia such as Christian-majority areas in Maluku, Minahasa and others would refuse to join the Islamic state. ${ }^{25}$ However Wahid Hasyim accepts to be openhearted, wise and moderate, that based on Hatta's view of his consideration that Indonesia should be united finally together with the legal-formal Islamic group agreed to erase the sentence which symbolically reads a particular religion. ${ }^{26}$ This explanation has proven that untouched relates to spatial practices, this refers to the arena of social activity and relations practices that allow the formation of a space (Indonesian independence), - apart from the absence of historical records at the Plenary Session 1 BPUPKI relating to speeches or brief notes from groups who fought for an Islamic state legally. On the other hand, it is as if an Islamic group or group is opposed to a nationalist group. It should be noted that representatives of national groups are also mostly Muslim, so that the term "groups of Muslims" without additional information about their political objectives is not suitable for use as a discourse in viewing spatial practices.

\section{THE NEXT CONCEPT WAS BUILT BY THE PRESIDENTIAL DECREE OF JULY 5, 1959}

On August 17, 1945, as Indonesia's independence day and following 18 August 1945 representatives of the legal-formal Islamic group (Islamism group) agreed to the abolition proposal. Indonesian Independence and the 1945 Constitution have been determined to apply to the Unitary State of the Republic of Indonesia as 'representational spaces' ${ }^{27}$. Thus, with this explanation that the holding of the first

${ }^{25}$ Departemen Pendidikan dan Kebudayaan, Tokoh-Tokoh Badan Penyelidik Usaha-Usaha Persiapan Kemerdekaan Indonesia II, 13-14; Bahtiar Effendy, Islam Dan Negara: Transformasi Pemikiran Dan Praktik Politik Islam Di Indonesia (Jakarta: Paramadina, 1998), 88-89.

${ }^{26}$ Effendy, Islam Dan Negara: Transformasi Pemikiran Dan Praktik Politik Islam Di Indonesia, 98.

${ }^{27}$ Representational spaces, embodying complex symbolisms, sometimes coded, sometimes not, linked to the clandestine or underground side of social life, as also to art (which may come eventually to be defined less as a code of space than as a code of representational spaces). Lefebvre, The Production of Space, 33. 
elections in Indonesia which took place democratically was not born with no reason, the birth of the 29 September 1955 election was the result of a previous compromise in the early days of Indonesian independence by the nation's founders. Ideological controversies between representatives of legal-formal Islamic groups and nationalist groups are known to be quite harmonious, ranging from 1950-1953. The constitutional democratic system (1950-1959) $)^{28}$ is part of an interesting demonstration of the political position of representatives of legal-formal Islamic groups. ${ }^{29}$ Nevertheless, in the first general election in 1955, its emergence or reappearance took place fiercely at the Constituent Assembly (1956-1959). ${ }^{30}$

The 1955 General Elections only gave $43.5 \%$ of the votes to Islamic parties. ${ }^{31}$ As for Shafi'i Maarif explains:

"The final results of the 1955 General Elections in Indonesia showed that Islamic parties received less than 45 percent of the total votes. According to the 1950 Constitution which also regulates the General Election, a new constitution becomes valid if the draft is approved by at least $2 / 3$ of the members who present at the deliberation. Thus, based on this provision, a constitutional struggle aimed at creating an Islamic state or a state based on Islam becomes impossible. However, the debate over the basic problems of the state went on fiercely until the Constituent Assembly was dissolved by President Sukarno in July 1959 in an attempt to create a new political order known as Guided Democracy (1959-1965)" 32

Seeing the continuation of history from pre-independence to the debate in the Constituent Assembly, the debate over space to control Indonesia, According to the writer here, it will never end even though the journey between Islamism and Islamic groups has experienced a harmonious atmosphere in 1950-1953. After passing through this phase, it turns out that political Islamic movements evolves to new movements (reproduction), to dominate the state in Indonesia.

${ }^{28}$ Effendy, Islam Dan Negara: Transformasi Pemikiran Dan Praktik Politik Islam Di Indonesia, 105.

${ }^{29}$ Effendy, 94.

${ }^{30}$ Effendy, 104-5.

${ }^{31}$ Effendy, 94.

${ }^{32}$ Ahmad Syafii Maarif, Studi Tentang Percaturan Dalam Konstituante; Islam Dan Masalah Kenegaraan (Jakarta: LP3S, 1985), 124. 
This is not without reason, because documents or historical records of Indonesia's independence clearly illustrate the debate between "Islamism groups" and "Islamic groups". 33

As for the Islamism group as described earlier, the author understands it as a group whose forms of political and social action want public life and politics with full sharia enforcement. They aim to establish an Islamic state in Indonesia and the Islamic caliphate. ${ }^{34}$ The term Islamism reflects an ideology because it adds the suffix 'ism'. Therefore Islamism is not Islam, but a political interpretation of religion. ${ }^{35}$ Furthermore, Peter R. Demant views that Islamism is an ideology that is anti-Western and modern, more clearly as follows:

"The Islamic world today is in turmoil, and its consequences afect the rest of the world... Whitin this trend, a growing minority identifies with a politicized, anti-Western, and antimodern reading of their rligion, called Islamism...endorses the use of violence and terrorism against the West to attain their goals..."Political Islam" and "Islamic revivalism" are acceptable, but limited. Others simply use "radical" or "militant" Islam. In Arabic islamiyya is used, simplest and best: Islamism." "36

The explanation above regarding Islamism groups at least leads to ideological attitudes that tend to be radical and militant or commensurate with fundamentalism. On the other hand, this Islamic group is a form of political and social action to fight for Islamic law without having to establish an Islamic state, ${ }^{37}$ in other words, it can also be interpreted as a good Islam and use democratic mechanisms

${ }^{33}$ To simplify the discussion according to the theme, and the context of the author specifically this study maps by using nomenclature such as; the debate between Islamism and Islamic groups. Because if it is patterned into; Islamism (top-down) and/ or towards neo-fundamentalism (bottom-up) as illustrated by Olivier Roy, does not seem relevant enough to read the complexity of the Islamic movement in Indonesia. Olivier Roy, The Failure of Political Islam, ed. Translated by Carol Volk (Cambridge, Mass: Harvard University University Press, 1994), 24.

${ }^{34}$ Priyono, "Masa Depan Islam-Politik Dan Islamisme Di Indonesia," 3; Ahmad Asrori, "Radikalisme Di Indonesia: Antara Historitas Dan Antropisitas," Kalam: Jurnal Studi Agama Dan Pemikiran Islam 9, no. 2 (2015): 257.

${ }^{35}$ Bassam Tibi, Islamism and Islam (New Haven, London: Yale University Press, 2012), 7 .

${ }^{36}$ Peter R. Demant, Islam vs. Islamism: The Dilemma of the Muslim World (Wasport, Connecticut London: Praeger, 2006), 89.

${ }^{37}$ Asrori, "Radikalisme Di Indonesia: Antara Historitas Dan Antropisitas," 257. 
to fight for Islamic values and promote the substance of Islam in the public space rather than Islam as a formality in the political space. ${ }^{38}$

Islamic groups commonly refer $\mathrm{r}$ ed to as Islamic Societies, this term can be used in very heterogeneous societies, cultures and nations. Islamic groups are more committed to the values identified from western societies, not the least of which is developing traditional Islamic concepts that consider changes more towards modernization. ${ }^{39}$

Starting with a statement the next concept built on, referring to the direction of the Presidential Decree of 5 July 1959, it is seen from the content contained therein. Delivering this term, at least B. $\mathrm{J}$ Boland gives a portrait of what happened at the birth of the decree, including:

Based on these considerations, the Presidentdereed (1) that the Constituent Assembly was disolved, and (2) thet the return to the Constitution of 1945 had taken place. Added to this Decree was the announcement that, as soon as possible, a provisional People's Congress would be brought into being, consisting of the members of parliement doubled by the appointment of representatives from various parts of Indonesia and representatives of certain groups of the population; furthermore a Supreme Advisory Council would be set up (both bodies were mentioned in the 1945 Constitution). The Decree wa signed "in the name of the people of Indonesia" by Soekarno as President of Indonesia and Commander-in-Chief of the Armed Forces. For our subject the most important of the abovementioned "considerations" is the fifth and last one, which states that the 1945 Constitution is inspired by the Djakarta Charter and that these two are linked together in unity. ${ }^{40}$

The content of the decree seems to be delivering the next concept built on the 1945 constitution is inspired by the Djakarta Charter. This historical document that led to a long story on the debate and political struggle over the next space, in this case, the 2019

${ }^{38}$ Muhammad Wildan, “Aksi Damai 411-212, Kesalehan Populer, Dan Identitas Muslim Perkotaan Indonesia," Maarif Institut Fr Culture and Humanity 11, no. 2 (2016): 199-200.

${ }^{39}$ Caroline Cox and John Marks, The "West", Islam and Islamism: Is Ideological Islam Compatible with Liberal Democracy? (London: Civitas: Institut for the Study of Civil Society, 2003), 4-5.

${ }^{40}$ Boland, The Struggle of Islam in Modern Indonesia, 100. 
Presidential Election. Given that the presidential decree is a single policy on Soekarno's interpretation, but the writer can interpret it that the effort is only in the realization of the interests of the nation and state without having to become part of certain groups. This is very evident in the contents of the decree as explained by B. J. Boland above. It is interesting to quote a statement, as follows:

"The reflection from the beginning of the establishment of this nation-state needs to be revisited again, that the struggle between the Islam politics and the state actually had already taken place and was directly confronted formally to find a way out and it could also be agreed wisely together. Although the friction is very sharp between the interests of each group, the resulting solution can be felt until now, that the Unitary State of the Republic of Indonesia is neither an Islamic state nor a Secular state (separating religion and state). Instead, the it is known as the Religious Nation State, which means that Indonesia is a country that upholds religious values." 41

However, undeniably today it seems that what is happening is a debate between Islamism and Islamic groups. The debates seemingly continues in the following episodes, even the dynamics of the battle are difficult to predict its ending. The most basic thing about the rise of Islamism is the call to realize Islamic sharia and jihad. Noorhadi in his explanation emphasized:

"The wave of Islamist militancy marked by the mounting call for the shari'a and jihad has increasingly been seen as threatening three principles of democratic life: (1) the raison d'étre of the rechtstaat (law state) and the rule of law, (2) the sovereignty of the people, and (3) the unity and plurality of Indonesian society. These three principles demand that state legislatures should be built, enforced, and developed in accordance with democratic principles. ${ }^{42}$

${ }^{41}$ Lubis, Ilmu Hukum Dalam Simpul Siyasah Dusturiyah: Refleksi Atas Teori Dan Praktek Hukum Tata Negara Di Indonesia, 186-87.

${ }^{42}$ Noorhaidi Hasan, "Post-Islamism in Indonesia," in Post-Islamism:The Changing Faces of Political Islam, ed. Asef Bayat (New York, USA: Oxpord University Press, 2013), 168. 
Islamism groups exist as a 'revivalist' trend to revive Islam, both through the social and political dimensions of society in general. ${ }^{43}$ Today, the Islamist movement seems to metamorphose and reproduce conceptual patterns in a sufficiently calculated way because it is very clear that in the Presidential Decree 5 July 1959, the Jakarta Charter had adopted the spirit of the 1945 Constitution, - what is contained in it illustrates that the Jakarta Charter and The 1945 Constitution is a series of unity with the constitution. This has become the basis of Islamism groups to continue to revive the movement to establish an Islamic state, such as Habib Rizieq and FPI and their followers in various circles, both from the elite-people, national-local who always rely on the struggle to realize a state based on Islamic Sharia with da'wah and hizbah and constitutional jihad. The basis of his struggle was found in the Decree of President Soekarno 15 July $1959,{ }^{44}$. Furthermore, President Soeharto in the New Order (New Order) acknowledged that the Decree of President Soekarno became a reference to be firmly held and then implemented, ${ }^{45}$ so that the basis for the struggle of Islamism groups this is what I mean by the next concept built on Decree of 5 July 51959.

\section{ISLAMISM AND ISLAMIC GROUPS}

The portrait of the victory of the Islamic group for me, today is no longer a debate that revolves around only the claim of "failure of Political Islam". It is precisely for me today, that the stage of democracy is filled with the involvement of Islamic politics in Indonesia. Space political debate between Islamism and Islamic groups in the 2019 Presidential Election, can be mapped between; adhesion of Islamism by reproducing political movements under the concept of space (representations of space) "NKRI Bersyariah" 46

${ }^{43}$ Andrea Mura, The Symbolic Scenarios of Islamism: A Study in Islamic Thought (Enland, USA: Ashgate, 2016), 13.

${ }^{44}$ Ali Akhbar Abaib Mas Rabbani Lubis, "Rethingking the Book of Al-'Aql AlSiyasi Al-'Arabi and Indonesia Political Phenomenon," Jurnal Penelitian 17, no. 1 (2020): 68 .

${ }^{45}$ This was explained during a face-to-face activity with Indonesian Air Force officers at a family farm in Tapos, West Java on April 17, 1994, see HM Soeharto in https://youtu.be/GQSCSCcL_XNI, accessed on 3/7-2020, at 21:18.

${ }^{46}$ The term NKRI Bersyari'ah was introduced by M. Rizieq Syihab in his work entitled "Wawasan Kebangsaan Menuju NKRI Bersyariah" published by Islam Press (Syihab, 2013) and also orated during the 21st FPI Anniversary by Habib Rizieq who 
with the orientation to support Prabowo-Sandi (Presidential and Vice-Presidential Candidates 2019-2024) as representatives who can voice their aspirations and adhesion to Islamic groups represented by Nahdhatul Ulama (NU) ${ }^{47}$ and Muhammadiyah. ${ }^{48}$ This Islamic group still maintains the state of Indonesia as NKRI without the addition of the word "shari'ah", further strengthened by bringing up KH. Ma'ruf Amin is a representative of the Islamic group as a candidate for Vice President alongside Jumbowi's incumbent as a candidate for President (2019-2024).

I simply classify this political space struggle as a struggle for and control of the domination of power in Indonesia, simply put between Islamism and Islamic groups. Again, the representational spaces produced (social products) do not at all illustrate that Islamic politics in Indonesia has failed. ${ }^{49}$ Election stage in Indonesia (read: 2019 Presidential Election) precisely shows that Islamic politics holds the control of the domination of national political power because both camps are equally involved in fighting for Islam and the State. Only the style and direction of movement are different, such as the Islamism group fighting on behalf of the "NKRI Bersyariah" 50 and Islamic groups such as NU represented by KH. Ma'ruf Amin fought

spoke via video from Mecca and broadcast live on the Front TV Youtube account, titled "Milad FPI 21" on August 24, 2019.

${ }^{47}$ History records, since it was founded in 1926, NU participated in assisting the birth of the Republic of Indonesia and guarding it against various threats. Moh. Rosyid, "Muktamar 2015 Dan Politik NU Dalam Sejarah Kenegaraan," Yudisia 6, no. 1 (2015): 224.

${ }^{48}$ Pancasila State is the result of a national consensus (dar al- 'ahdi) and a place of proof or testimony (dar al-shahadah) to be a safe and peaceful state (dar al-salam) towards a life that is advanced, just, prosperous, dignified, and sovereign under the auspices of Allah Swt pleasure. Pimpinan Pusat Muhammadiyah, "Negara Pancasila Sebagai Darul Ahdi Wa Syahadah" (Makassar, 2016), 12.

${ }^{49}$ This is the author's reason for stating that Olivier Roy considers that Islamism experienced political failure to move towards "apolitical attitude" (neofundamentalism), only looking from a small angle on the empirical development of Islamic political practices from the Muslim Brotherhood organization to the FIS, Afghan jihad to Afghanistan on Iran's Shiite revolution. Olivier Roy, Gagalnya Islam Politik (Jakarta: PT Serambi Ilmu Pustaka, n.d.), xi-xii.

${ }^{50}$ Denny JA, "NKRI Bersyariah Atau Ruang Publik Yang Manusiawi? (Seri Renungan Singkat Seputar Isu Pilprs 2019)," in NKRI Bersyariah Atau Ruang Publik Yang Manusiawi? Tanggapan 21 Pakar Terhadap Gagasan Denny JA, ed. Editor Satrio Arismunandar (Depok: Cerah Budaya Indonesia, 2019), 1. 
on behalf of the Republic of Indonesia with the term "darul mitsaq", 51 while Muhammadiyah fought on behalf "darul ahdi wa syahadah", 52 Here the authors present a complete table listing the 2019 presidential nominations and the 2019 presidential election vote count results (version 26 October 2019), including:

\section{Table 1}

List of 2019 Presidential Election Candidates in Figure ${ }^{53}$

\begin{tabular}{lll}
\hline - Election Numbers & -1 & -2 \\
\hline - Candidate Name & - Ir. H. Joko Widodo & - H. Prabowo Subianto \\
- Gender & - Male & - Male \\
- Presidential & - Incumbent & - Private \\
$\quad$ Candidate Job & & \\
- Suara, H. & Suara, Ir. H. \\
- Prabowo & & Joko Widodo - \\
- Subianto - H. & & Prof. Dr. (H.C) \\
- Sandiaga & & KH Ma'ruf \\
Salahuddin... & & Amin, 55.32\% \\
- & &
\end{tabular}

Figure 1

List of 2019 Presidential Election Results in Figure ${ }^{54}$

The KPU results show that the struggle for political space in the 2019 presidential election was won by the Jokowi-Ma'ruf pair with a ratio of $55.32 \%$ percentage of votes $(84,646,196$ votes $)$, while the Prabowo-Sandi pair with a percentage ratio of $44.68 \%$ (number total votes: $68,357,813$ ) of the total 813,336 TPS version on 26 October 2019, throughout Indonesia $(99,51496 \%) .{ }^{55}$ The victory

${ }^{51}$ See full at; https://www.nu.or.id/post/read/107831/kh-maruf-amin-sebutindonesia-is-darul-mitsaq. Accessed 10-10-2019 at 16:22.

${ }^{52}$ Muhammadiyah, "Negara Pancasila Sebagai Darul Ahdi Wa Syahadah," 12.

${ }^{53} \mathrm{https} / / /$ infopemilu.kpu.go.id/pilpres2019. Accessed 26-10-2019 at 16:56.

${ }^{54} \mathrm{https} / / /$ pemilu2019.kpu.go.id//ppwp/hitung-suara. Accessed 26-10-2019 at 17:18.

${ }^{55}$ Ibid., 
of the Jokowi-Ma'ruf pair (2019-1024), in the 2019 Presidential Election as President and Vice President of the Republic of Indonesia was a victory of the Islamic group. Officially Jokowi-Ma'ruf's victory attended his inauguration which was held at the MPR Building, Parliament Complex, Senayan, Central Jakarta. ${ }^{56}$ However, throughout the historical record that Islamic groups officially always occupy political spaces (representational spaces) within the knot of the Unitary Republic of Indonesia (NKRI).

The Islamism group can be marked as starting in 2016-2017, on mass-based actions such as the Defending Islamic Action. At that time the gathering of Muslims in the capital city of Jakarta intending to prosecute Ahok as a candidate for the Governor of DKI Jakarta to be tried for alleged blasphemy cases, of course, the state and the government were targeted to immediately bring Ahok to justice, the impact of mobilization on Islamic Defending Action emerged anti-Ahok sentiment in class social or identity. The political expression indicates an Islamization effort that wants a change in the constitution into Islamic law and a ban on non-Muslim leaders in Muslim-majority countries. ${ }^{57}$ Of course, the mass action succeeded in influencing the masses only by relying on the internet, both in the form of short messages, memes and propaganda images. ${ }^{58}$ The mass action developed to be projected in the 2019 Election, this event greatly influenced political behaviour and choices because of the mobilization in the Action of Defending Islam. Although in the end, it is not too significant to influence the simultaneous election vote on 17 April 2019, there are several indicators regarding the weak influence of this Islamism group, including: first, there is no direct effect of Islamic Defendant Action on the increase or decrease in the votes of candidate pairs. Secondly, in terms of the distribution of supporters and masses of votes, the Defending of Islam was relatively

${ }^{56} \mathrm{https} / / / \mathrm{m}$. liputan6.com/news/read/4090389/momen-pelantikan-jokowi-marufamin-sebagai-presiden-dan-wapres-republik-indonesia. Accessed 21-10-2019 at $18: 20$

${ }^{57}$ Rangga Kusumo and Hurriyah, "Populisme Islam Di Indonesia: Studi Kasus Aksi Bela Islam Oleh GNPF-MUI Tahun 2016-2017,” Jurnal Politik 4, no. 1 (2018): 91-92.

${ }^{58}$ Muzayyi Ahyar, “Aksi Bela Islam: Islamic Clicktivism and the New Authority of Religious Propaganda in the Millenial Age in Indonesia," Indonesian Journal of Islam and Muslim Societies 9, no. 1 (2019): 17. 
distributed to the two pairs of candidates, both Jokowi and Prabowo. Third, the parties that are close to the Islamic Defendant Action movement do not get huge political incentives after the DKI Jakarta Election. $^{59}$

The explanation of the political struggle over the Unitary Republic of Indonesia between Islamism and Islamic groups basically as explained is to hold control of the domination of national political power, because both camps are equally involved in fighting for Islam and the State. Only the style and direction of movement are different, the resulting social space is a social product (social space is a social product) is an attempt to control and dominate state power, for example, the history of Indonesia's independence wants its territorial power to be free from colonialism. Then after independence until the present, there are various perceptions and concepts about the state that will be used as a representation of space as mentioned earlier. The struggle for political space between the Unitary Republic of Indonesia between Islamism and Islamic groups in the 2019 Presidential Election, has become a reality that there is no failure in political Islam. The victory of political Islam in the knot of Islamic groups can be traced throughout the history of Indonesia's independence, the cycle of the holder of power control (representations of space) such as the replacement of the President of Indonesia from its inception until the present is always occupied by representatives of Muslims, from political parties-even the majority in control are representatives of Muslims, community organizations that always fight for the aspirations of the people especially the aspirations of the majority Muslims are Muslim organizations, and the people who dominate the population are the majority of Muslims. It should also be noted that existing regulations in Indonesia have legal principles that are compatible with Islamic principles. ${ }^{60}$ The only thing that needs to be fought after this inauguration is always to fill and decorate this space humanely and religiously because human and religious things are indeed a typical form of the characteristics of Indonesian civilization.

${ }^{59}$ Arya Fernandes, "Politik Identitas Dalam Pemilu 2019: Proyeksi Dan Efektifitas," Center for Strategic and International Studies, 1 (Jakarta, 2018), 6-8.

${ }^{60}$ Lubis, Ilmu Hukum Dalam Simpul Siyasah Dusturiyah: Refleksi Atas Teori Dan Praktek Hukum Tata Negara Di Indonesia, 174. 


\section{CONCLUSION}

Research with a spatial practice approach, representations of space, representational spaces has shown that the struggle for the NKRI space politics between Islamism and Islamic groups conclude that basically that the political cycle of democracy in Indonesia is more to holding control over the dominance of national political power because both groups are equally involved in fighting for Islam and the State. The debate over space to control Indonesia in my opinion here will never end. Moreover, Islamism, in particular, will continue to give birth to new movements (reproduction) to dominate the state in Indonesia.

The struggle for political space within the Unitary Republic of Indonesia between Islamism and Islamic groups in the 2019 Presidential Election, has become a reality that there is no failure in political Islam. Only the style and direction of movement are different, such as; Islamism groups, for example, one of their movements fought in the name of "NKRI Bersyariah" and Islamic Groups such as NU, represented by KH. Ma'ruf Amin fought on behalf of NKRI with the term "darul mitsaq", while Muhammadiyah fought on behalf of the State of Pancasila with the terms offered "darul ahdi wa syahadah".

The cycle of Indonesian democracy over the victory of political Islam that refers to Islamic groups can be traced throughout the history of Indonesia's independence, which is always fighting between Islamism groups fighting for an Islamic state and Islamic groups fighting for substantial values by defending the Unitary Republic of Indonesia. Of course, only those groups that appear to be fighting in the democratic cycle in Indonesia are the President of the Republic of Indonesia from the very beginning of the Unitary Republic of Indonesia to the present, always held by Muslim representatives, political parties up to now who hold the organizational structure in control are Muslim representatives, community organizations too, and the majority of the population in Indonesia constitutes a majority of Muslims. Therefore the contribution of the approach used in this research shows what appears in the cycle of democracy in Indonesia in the struggle for the NKRI space, which is always repeated between Islamism and Islamic groups. 


\section{REFERENCES}

Ahyar, Muzayyi. “Aksi Bela Islam: Islamic Clicktivism and the New Authority of Religious Propaganda in the Millenial Age in Indonesia." Indonesian Journal of Islam and Muslim Societies 9, no. 1 (2019): 1-29.

Asrori, Ahmad. "Radikalisme Di Indonesia: Antara Historitas Dan Antropisitas." Kalam: Jurnal Studi Agama Dan Pemikiran Islam 9, no. 2 (2015).

Boland, B. J. The Struggle of Islam in Modern Indonesia. Leiden, The Netherlends: Brill, 2014.

Cox, Caroline, and John Marks. The "West", Islam and Islamism: Is Ideological Islam Compatible with Liberal Democracy? London: Civitas: Institut for the Study of Civil Society, 2003.

Demant, Peter R. Islam vs. Islamism: The Dilemma of the Muslim World. Wasport, Connecticut London: Praeger, 2006.

Departemen Pendidikan dan Kebudayaan. Tokoh-Tokoh Badan Penyelidik Usaha-Usaha Persiapan Kemerdekaan Indonesia II. Jakarta: Proyek Inventarisasi dan Dokumentasi Sejarah Nasional, Direktorat Sejarah dan Nilai Tradisional, 1993.

Effendy, Bahtiar. Islam Dan Negara: Transformasi Pemikiran Dan Praktik Politik Islam Di Indonesia. Jakarta: Paramadina, 1998.

Fernandes, Arya. "Politik Identitas Dalam Pemilu 2019: Proyeksi Dan Efektifitas." Center for Strategic and International Studies. 1. Jakarta, 2018.

Hasan, Noorhaidi. "Post-Islamism in Indonesia." In PostIslamism:The Changing Faces of Political Islam, edited by Asef Bayat. New York, USA: Oxpord University Press, 2013.

Hilmy, Masdar. "The Configuration of Radical Islamism in Indonesia: Some Contemporery Assessments and Trajectories." Al-Tahrir 14, no. 1 (2014): 1-21.

JA, Denny. "NKRI Bersyariah Atau Ruang Publik Yang Manusiawi? (Seri Renungan Singkat Seputar Isu Pilprs 2019)." In NKRI Bersyariah Atau Ruang Publik Yang Manusiawi? Tanggapan 
21 Pakar Terhadap Gagasan Denny JA, edited by Editor Satrio Arismunandar. Depok: Cerah Budaya Indonesia, 2019.

Karim, Syahrir, Samsu Adabi Mamat, and Bayu Taufiq Possumah. "Islamism and Democratization in Indonesia Post-Reformation Era: Socio-Political Analysis." International Journal of Islamic Thought 6 (2014): 79-96.

Kusumo, Rangga, and Hurriyah. "Populisme Islam Di Indonesia: Studi Kasus Aksi Bela Islam Oleh GNPF-MUI Tahun 20162017." Jurnal Politik 4, no. 1 (2018): 87-113.

Latif, Yudi. Negara Paripurna; Historitas, Rasionalitas, Dan Aktualisasi Pancasila. 2nd ed. Jakarta: PT Gramedia Pustaka Utama, 2011.

Lefebvre, Henri. The Production of Space. Edited by Tranlated by Donald Nicholson-Smith. Oxford UK, Cambridge, Massachusetts, USA: Basil Blackwell, 1991.

Lubis, Ali Akhbar Abaib Mas Rabbani. Ilmu Hukum Dalam Simpul Siyasah Dusturiyah: Refleksi Atas Teori Dan Praktek Hukum Tata Negara Di Indonesia. Yogyakarta: Semesta Aksara, 2019.

—. "Rethingking the Book of Al-'Aql Al-Siyasi Al-'Arabi and Indonesia Political Phenomenon." Jurnal Penelitian 17, no. 1 (2020): 67-80.

Maarif, Ahmad Syafii. Studi Tentang Percaturan Dalam Konstituante; Islam Dan Masalah Kenegaraan. Jakarta: LP3S, 1985.

MD, Moh. Mahfud. "Pancasila Sebagai Hasil Karya Dan Milik Bersama.” Kongres Pancasila. Yogyakarta, 2009.

. Perdebatan Hukum Tata Negara. Jakarta: Rajawali Pers, 2010. 2011.

Muhammadiyah, Pimpinan Pusat. "Negara Pancasila Sebagai Darul Ahdi Wa Syahadah.” Makassar, 2016. 
Mura, Andrea. The Symbolic Scenarios of Islamism: A Study in Islamic Thought. Enland, USA: Ashgate, 2016.

Priyono, AE. "Masa Depan Islam-Politik Dan Islamisme Di Indonesia." Monograf Embun Kalimasada, no. 2 (2019).

Rosyid, Moh. "Muktamar 2015 Dan Politik NU Dalam Sejarah Kenegaraan." Yudisia 6, no. 1 (2015).

Roy, Olivier. Gagalnya Islam Politik. Jakarta: PT Serambi Ilmu Pustaka, n.d.

. The Failure of Political Islam. Edited by Translated by Carol Volk. Cambridge, Mass: Harvard University University Press, 1994.

Saifudin. "Lahirnya UUD 1945: Suatu Tinjauan Historis Penyusunan Dan Penetapan UUD 1945." Unisia 3, no. 49 (2003).

Sebastian, Leonard C., and Alexander R. Arifianto. "From Civil Islam toward NKRI Bersyariah? Understanding Rising Islamism in Post-Reformasi Indonesia." In Proceedings of the Third International Conference on Social and Political Sciences (ICSPS 2017), 301-16, 2017.

Sidang-Sindang, Himpunan Risalah. Dari Badan Penyelidik Usaha Persiapan Kemerdekaan Indonesia (BPUPKI) Tanggal 29 Mei 1945-16 Juli 1945 dan Panitia Persiapan Kemerdekaan Indonesia (PPKI) Tanggal 18 dan 19 Agustus 1945. Indonesia, n.d.

Tibi, Bassam. Islamism and Islam. New Haven, London: Yale University Press, 2012.

Tomsa, Dirk. "Moderating Islamism in Indonesia: Tracing Patterns of Party Change in the Prosperous Justice Party." Political Research Quarterly 65, no. 3 (2012): 486-98.

Wildan, Muhammad. “Aksi Damai 411-212, Kesalehan Populer, Dan Identitas Muslim Perkotaan Indonesia." Maarif Institut Fr Culture and Humanity 11, no. 2 (2016). 
https://www.nu.or.id/post/read/107831/kh-maruf-amin-sebutindonesia-adalah-darul-mitsaq. Diakses pada 26-10-2019 pada pukul 16:22.

https://infopemilu.kpu.go.id/pilpres2019. Diakses pada 26-10-2019 pada pukul 16:56.

https://pemilu2019.kpu.go.iď//ppwp/hitung-suara. Diakses pada 26-10-2019 pada pukul 17:18.

https://m.liputan6.com/news/read/4090389/momen-pelantikanjokowi-maruf-amin-sebagai-presiden-dan-wapres-republikindonesia. Diakses pada 21-10-2019 pukul 18:20.

http://youtu.be/Ju4wvLBINdE. Diakses pada 9-01-2020 pukul 14:00 